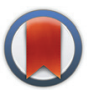

CrossMark \&lick for updates

Cite this: Analyst, 2016, 141, 2140

Received 21st January 2016, Accepted 22nd February 2016

DOI: $10.1039 / c 6 a n 00141 f$

www.rsc.org/analyst

\section{Analytically useful blue chemiluminescence from a water-soluble iridium(III) complex containing a tetraethylene glycol functionalised triazolylpyridine ligand $\uparrow$}

\author{
Zoe M. Smith, ${ }^{a}$ Emily Kerr, ${ }^{a}$ Egan H. Doeven, ${ }^{b}$ Timothy U. Connell, ${ }^{a, c}$ \\ Neil W. Barnett, ${ }^{a}$ Paul S. Donnelly, ${ }^{c}$ Stephen J. Haswell ${ }^{b}$ and Paul S. Francis ${ }^{\star a}$
}

\begin{abstract}
We examine $[\text { Ir(df-ppy })_{2}(\text { pt-TEG) }]^{+}$as the first highly water soluble, blue-luminescent iridium(III) complex for chemiluminescence detection. Marked differences in selectivity were observed between the new complex and the conventional $\left[R u(b p y)_{3}\right]^{2+}$ reagent, which will enable this mode of detection to be extended to new areas of application.
\end{abstract}

Cyclometalated iridium(III) complexes exhibiting high luminescence efficiencies and a wide range of emission colours ${ }^{1}$ are seen as promising alternatives to the ruthenium(II) complexes traditionally employed for photoluminescence, chemiluminescence and electrochemiluminescence (ECL). The use of iridium(III) complexes offers opportunities to manipulate detection selectivity, shift the emission into the most sensitive wavelength range of conventional photomultiplier tubes, and develop multicolour detection systems. ${ }^{2,3}$ However, the poor aqueous solubility of many available iridium(III) complexes has limited their application in these areas. In cases where only low concentrations of the luminophore are required, such as photoluminescence protein staining, cellular imaging and molecular probes, ${ }^{4,5}$ or ECL labelling for immunoassay, ${ }^{6}$ sufficient solubility has been derived by including a neutral ligand to impart an overall positive charge to the complex, or a derivative containing sulfonate or saccharide groups. ${ }^{3,4,7-9} \$$ For chemiluminescence detection systems in which the metal complexes are used at relatively high concentrations to detect

\footnotetext{
${ }^{a}$ Centre for Chemistry and Biotechnology, School of Life and Environmental Sciences, Deakin University, Locked Bag 20000, Geelong, Victoria 3220, Australia. E-mail: paul.francis@deakin.edu.au

${ }^{b}$ Centre for Regional and Rural Futures. Deakin University, Locked Bag 20000, Geelong, Victoria 3220, Australia

${ }^{c}$ School of Chemistry and Bio21 Molecular Science and Biotechnology Institute, University of Melbourne, Melbourne, Victoria 3010, Australia

$\dagger$ Electronic supplementary information (ESI) available: Chemical structure of $\left[\mathrm{Ir}\left(\mathrm{ppy}-\mathrm{SO}_{3}\right)_{2}(\mathrm{pt}-\mathrm{TEG})\right]^{-}$, photograph of the luminescence, structure of compounds selected for the comparison, additional relative chemiluminescence responses, additional spectroscopic data, and calibration graphs. See DOI: 10.1039/ c6an00141f
}

reducing agents (such as tertiary amines) ${ }^{10}$ these approaches have not resulted in adequate solubility and/or have restricted emission wavelengths to regions of green to red light. Nevertheless, explorations of iridium(III) complexes as chemiluminescence reagents, ${ }^{7,9,11-13}$ have shown differences in the selectivity of their light producing reactions, and for some analytes, more intense emissions than those from analogous reactions with conventional ruthenium(II)-based reagents. ${ }^{7,9,12}$

We previously examined a series of chemiluminescence reactions of $\left[\operatorname{Ir}\left(\mathrm{C}^{\wedge} \mathrm{N}\right)_{2}(\mathrm{BPS})\right]^{-}$complexes ${ }^{9,12}$ (where $\mathrm{C}^{\wedge} \mathrm{N}$ represents the cyclometalating phenylisoquinoline (piq), phenylpyridine (ppy), phenylbenzothiazole (bt) or difluorophenylpyridine (dfppy) ligands, and BPS is bathophenanthroline disulfonate), which exhibited red, orange, yellow and green emissions, respectively. The BPS ligand imparted significant solubility in aqueous solution, but a 1:1 mixture of water: acetonitrile was required to prepare the reagents at $1 \mathrm{mM}^{9,12}$ Using a flowinjection analysis manifold, the reagents were oxidised with cerium(Iv) sulfate before reacting with a variety of analytes. Greater chemiluminescence intensities were generally obtained using $\left[\operatorname{Ir}(\mathrm{df}-\mathrm{ppy})_{2}(\mathrm{BPS})\right]^{-}$or $\left[\operatorname{Ir}(\mathrm{bt})_{2}(\mathrm{BPS})\right]^{-}$than with $\left[\mathrm{Ru}(\mathrm{bpy})_{3}\right]^{2+}$, but the blank responses from the reaction between oxidised iridium complexes and solvent were also greater, which reduced the anticipated improvements in the signal-to-blank ratios., ${ }^{9,12}$ The inclusion of the BPS ligand in these complexes also induced a bathochromic shift in the emission when compared to their homoleptic counterparts, restricting the highest energy emission, exhibited by $\left[\operatorname{Ir}(\mathrm{df}-\mathrm{ppy})_{2}(\mathrm{BPS})\right]^{-}$(Fig. 1b), to the green region of the spectrum $\left(\lambda_{\max }=549 \mathrm{~nm}\right.$; Fig. S1 in ESI $\left.\dagger\right),{ }^{9}$ whereas the corresponding neutral $\left[\operatorname{Ir}(\mathrm{df}-\mathrm{ppy})_{3}\right]$ complex (Fig. 1a), which is not soluble in water, emits blue light $\left(\lambda_{\max }=495 \mathrm{~nm}\right) .{ }^{15}$

In a previous attempt to create a water-soluble iridium(III) complex exhibiting blue chemiluminescence, ${ }^{9}$ we synthesised a sulfonated derivative of 1-phenyl-1,2,3-triazol-4-ylpyridine (STP) as an alternative ancillary ligand to BPS. Although blue chemiluminescence was observed from [Ir(df-ppy $\left.)_{2}(\mathrm{STP})\right]$ (Fig. 1c and S1†) upon reaction with cerium(Iv) sulfate and pharmaceuticals such as codeine, furosemide and ofloxacin, 
(a)

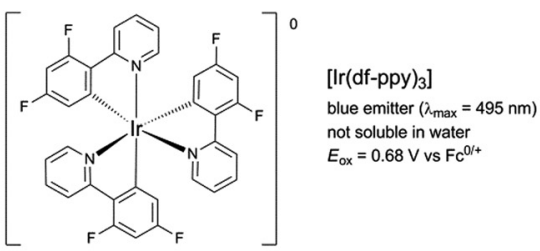

(b)

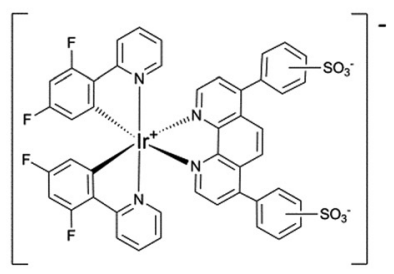

$\left[\mathrm{Ir}(\mathrm{df}-\mathrm{ppy})_{2}(\mathrm{BPS})\right]^{-}$

green emitter $\left(\lambda_{\max }=549 \mathrm{~nm}\right)$ reasonably soluble in water $E_{o x}=1.52 \mathrm{Vvs} \mathrm{Ag/AgC}$

(c)

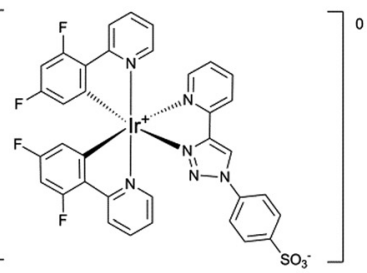

$\left[\operatorname{lr}(\mathrm{df}-\mathrm{ppy})_{2}(\mathrm{STP})\right]$

blue emitter $\left(\lambda_{\max }=453,482 \mathrm{~nm}\right)$ poorly soluble in water

(d)

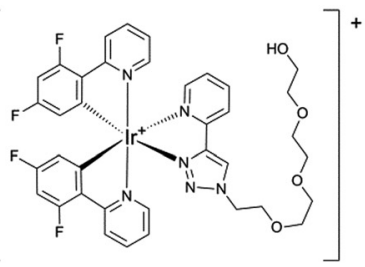

$[\text { Ir(df-ppy })_{2}($ pt-TEG $\left.)\right]^{+}$ blue emitter $\left(\lambda_{\max }=456,483 \mathrm{~nm}\right)$ $E_{0 x}=1.43 \mathrm{Vvs} \mathrm{Ag} / \mathrm{AgCl}$

Fig. 1 Comparison of $\left[\operatorname{lr}(\mathrm{df}-\mathrm{ppy})_{2}(\mathrm{~L})\right]^{n}$ complexes, where $\mathrm{L}$ is: 2-(2,4difluorophenyl)pyridinato (df-ppy) $i^{14,15}$ bathophenanthroline-disulfonate (BPS); ${ }^{9,12,16}$ 1-phenylsulfonate-1,2,3-triazol-4-ylpyridine (STP); ${ }^{9}$ or 2-triethoxyethanol[4-(2-pyridinyl)-1H-1,2,3-triazole-1-yl] (pt-TEG). ${ }^{16,17}$

the aqueous solubility of the complex was poor (limited to $\sim 10^{-5} \mathrm{M}$ ) and its chemiluminescence intensities (and signal/ blank ratios) were generally very low compared to those of $\left[\mathrm{Ru}(\mathrm{bpy})_{3}\right]^{2+}$ and the $\left[\operatorname{Ir}\left(\mathrm{C}^{\wedge} \mathrm{N}\right)_{2}(\mathrm{BPS})\right]^{-}$complexes. However, a close analogue of $\left[\operatorname{Ir}(\mathrm{df}-\mathrm{ppy})_{2}(\mathrm{STP})\right]$ bearing a polyethylene glycol substituent ([Ir(df-ppy) $)_{2}$ (pt-TEG) $]^{+}$; Fig. 1d) was recently identified as a promising candidate for ECL detection, ${ }^{16}$ with high aqueous solubility and co-reactant ECL signals with tri-npropylamine that were over twelve times greater than those of $\left.\left[\mathrm{Ru}(\mathrm{bpy})_{3}\right)\right]^{2+}$ when measured with a typical bialkali photomultiplier tube. Herein, we report our investigation of [Ir(dfppy $)_{2}(\text { pt-TEG) }]^{+}$as the first highly water-soluble iridium(III) complex exhibiting blue chemiluminescence.

We compared the chemiluminescence responses of [Ir(dfppy $\left.)_{2}(\mathrm{pt}-\mathrm{TEG})\right]^{+}$with that of $\left[\mathrm{Ru}(\mathrm{bpy})_{3}\right]^{2+}$ and a related iridium(III) complex that exhibits green luminescence ([Ir(ppy$\left.\mathrm{SO}_{3}\right)_{2}($ pt-TEG)]-, Fig. 2a, S2 and $\mathrm{S} 3 \dagger), \S$ using flow injection analysis methodology, and reagent concentrations of $1 \mathrm{mM}$, $0.1 \mathrm{mM}$ and $0.01 \mathrm{mM}$ (Fig. 3), representing the wide range adopted in previous analytical applications. ${ }^{10}$ The compounds selected for the comparison: codeine, furosemide, 1-(4-trifluoromethylphenyl)piperazine, 1-(4-trifluoromethylphenyl)piperidin-4-ol and ofloxacin (Fig. S4 $\dagger$ ), have previously
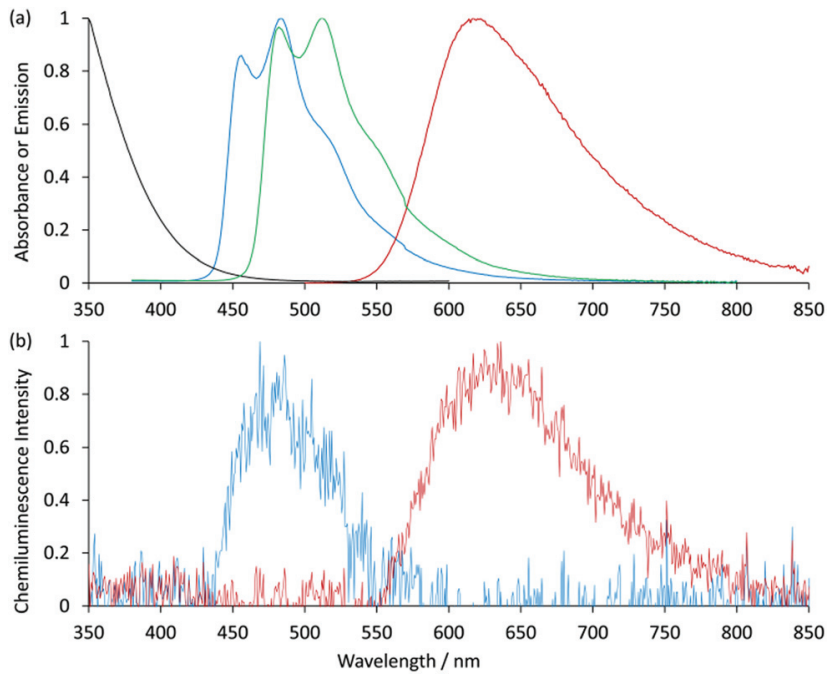

Fig. 2 (a) Normalised absorption spectrum of cerium(iv) sulfate (black line), and normalised photoluminescence emission spectra of [Ir(dfppy $)_{2}(\text { pt-TEG) }]^{+}$(blue line; $\left.\lambda_{\max }=456,483 \mathrm{~nm}\right),\left[\operatorname{lr}(\text { ppy-SO })_{3}(\mathrm{pt}-\mathrm{TEG})\right]^{-}$ (green line; $\left.\lambda_{\max }=482,512 \mathrm{~nm}\right)$, and $\left[\mathrm{Ru}(\mathrm{bpy})_{3}\right]^{2+}$ (red line; $\lambda_{\max }=$ $618 \mathrm{~nm}$ ), at $10 \mu \mathrm{M}$ in aqueous solution. (b) Normalised chemiluminescence spectra for $1 \mathrm{mM}\left[\operatorname{lr}(\mathrm{df}-\mathrm{ppy})_{2}(\mathrm{pt}-\mathrm{TEG})\right]^{+}$(blue line) and [Ru$\left.(\mathrm{bpy})_{3}\right]^{2+}$ (red line), with $1 \mathrm{mM}$ cerium(Iv) sulfate and $50 \mu \mathrm{M}$ furosemide. The chemiluminescence spectra were obtained under analytically relevant conditions by replacing the photomultiplier tube in the flow injection analysis manifold with a spectrometer with CCD detector. This enabled measurement of the chemiluminescence spectrum for each injection, during the time that the light-producing reaction mixture passed through the detection flow-cell. The vibrational structure in the photoluminescence emission spectrum of $\left[\operatorname{lr}(\mathrm{df}-\mathrm{ppy})_{2}(\mathrm{pt}-\mathrm{TEG})\right]^{+}$was not observed in the corresponding chemiluminescence spectrum due to the considerably lower resolution of the CCD spectrometer configuration.

been shown to elicit light upon reaction with various ruthenium(II) and iridium(III) complexes under acidic conditions using cerium(Iv) sulfate as an oxidant. ${ }^{9,18,19}$

Similar trends in the relative chemiluminescence intensities (and signal-to-blank ratios) were observed across the different reagent concentrations (Fig. 3 and S5†), but the three reagents exhibited markedly different selectivity. Using $\left[\mathrm{Ru}(\mathrm{bpy})_{3}\right]^{2+}$, the greatest intensities were elicited by ofloxacin and the piperidinol derivative, whereas using $\left[\operatorname{Ir}\left(\mathrm{ppy}^{-} \mathrm{SO}_{3}\right)_{2}(\mathrm{pt}-\right.$ $\mathrm{TEG})]^{-}$, the piperazine derivative elicited a much greater response than the other four compounds. Lower signals (and S/B ratios) were observed using $\left[\operatorname{Ir}(\mathrm{df}-\mathrm{ppy})_{2}(\mathrm{pt}-\mathrm{TEG})\right]^{+}$than $\left[\mathrm{Ru}(\mathrm{bpy})_{3}\right]^{2+}$, with the exception of the reaction with furosemide, which exhibited a four-fold greater S/B ratio with the blue-light emitting iridium(III) reagent (at $1 \mathrm{mM}$ and $0.1 \mathrm{mM}$ metal complex concentration).

The mechanism for the light-producing reactions of ruthenium- and iridium-complexes with various amine-containing compounds upon chemical or electrochemical oxidation involves numerous competing reaction pathways, ${ }^{20,21}$ the most dominant of which depends on the reaction conditions, and the properties of not only the metal complex, but also the amine and its radical oxidation products. The differences in 

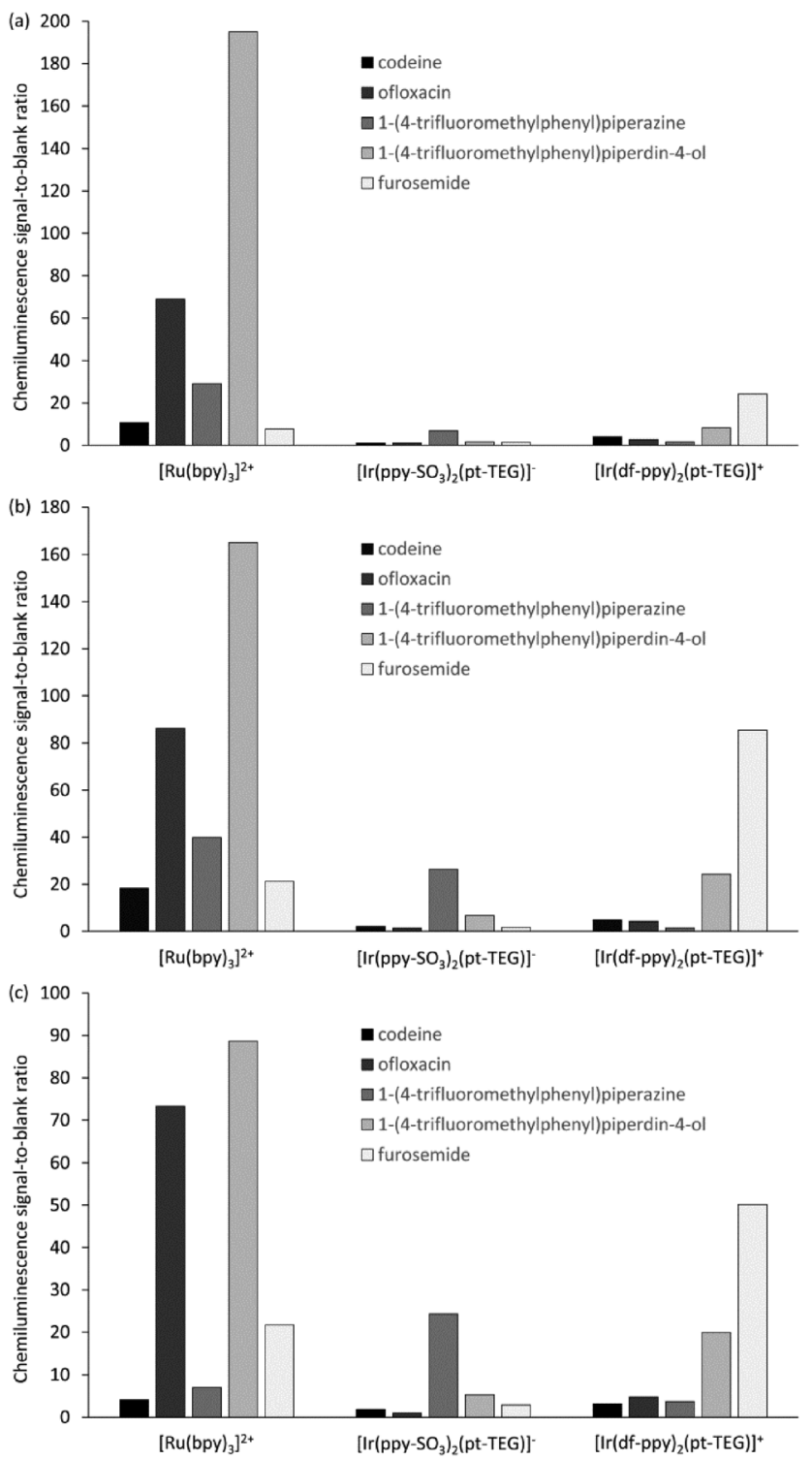

Fig. 3 Relative chemiluminescence (signal-to-blank) response for $\left[\mathrm{Ru}(\mathrm{bpy})_{3}\right]^{2+},\left[\operatorname{lr}\left(\mathrm{ppy}-\mathrm{SO}_{3}\right)_{2}(\mathrm{pt}-\mathrm{TEG})\right]^{-}$, and $\left[\operatorname{lr}(\mathrm{df}-\mathrm{ppy})_{2}(\mathrm{pt}-\mathrm{TEG})\right]^{+}$at (a) $1 \mathrm{mM}$, (b) $0.1 \mathrm{mM}$, and (c) $0.01 \mathrm{mM}$ reagent concentration, with cerium(Iv) sulfate $(1 \mathrm{mM})$ and various pharmaceuticals and related compounds $(1 \mu \mathrm{M})$, using flow injection analysis methodology.

the selectivity of the $\left[\mathrm{Ru}(\mathrm{bpy})_{3}\right]^{2+},\left[\operatorname{Ir}\left(\mathrm{ppy}_{-} \mathrm{SO}_{3}\right)_{2}(\mathrm{pt}-\mathrm{TEG})\right]^{-}$and $\left[\operatorname{Ir}(\text { df-ppy })_{2}(\text { pt-TEG })\right]^{+}$complexes towards these analytes can be attributed to factors such as their oxidising strength $\left(E_{\mathrm{Ox}}=\right.$ $1.06 \mathrm{~V}, 1.09 \mathrm{~V}$ and $1.43 \mathrm{~V}$ vs. $\mathrm{Ag} / \mathrm{AgCl}$, respectively ${ }^{16,20}$ ), ligand structure and overall charge $(2+, 1-$ and $1+$, respectively), which influence the rate of reaction leading to the emitting species. Similar reasoning can be made for the deleterious light-producing reaction with the solvent that produces the 'blank' response. The chemiluminescence intensity of the three complexes with any particular analyte (or the solvent) will also be limited by the luminescence quantum yield of each complex.
The optimum reagent concentration, in terms of chemiluminescence S/B ratios, was found to be both analyte and reagent dependent, in agreement with our previous investigations. ${ }^{12}$ In that prior work, stopped-flow experiments indicated that the changes in S/B ratio arose from the influence of concentration on the rates of the competing reactions of analyte and solvent with the reagent, coupled with the dependence of the chemiluminescence signal measured in a flowinjection analysis system on the reaction kinetics. ${ }^{12}$

The sensitivity of the $\left[\operatorname{Ir}(\mathrm{df}-\mathrm{ppy})_{2}(\mathrm{pt}-\mathrm{TEG})\right]^{+}$reagent towards furosemide compared to the other analytes under investigation is similar under certain conditions to that observed for [ $\operatorname{Ir}(\mathrm{df}-$ ppy $)_{2}$ (BPS)] $]^{-}$(Fig. 1b), ${ }^{12}$ which also has a much higher $E_{\text {ox }}$ $(1.52 \mathrm{~V} \text { vs. } \mathrm{Ag} / \mathrm{AgCl})^{16}$ than $\left[\mathrm{Ru}(\mathrm{bpy})_{3}\right]^{2+}$. Comparison of the chemiluminescence intensity of $\left[\mathrm{Ru}(\mathrm{bpy})_{3}\right]^{2+}$ and $[\operatorname{Ir}(\mathrm{df}-$ ppy $)_{2}$ (pt-TEG) $]^{+}$with compounds similar in structure to furosemide (Fig. 4 and 5) highlighted the remarkable difference in selectivity between the two reagents. Removing the aniline group from furosemide, or replacing its furan-2-ylmethyl substituent with a benzyl group on the anilinic nitrogen reduced the chemiluminescence intensity with $\left[\operatorname{Ir}(\mathrm{df}-\mathrm{ppy})_{2}(\mathrm{pt}-\mathrm{TEG})\right]^{+}$by an order of magnitude (Fig. 6). Piretanide, which possesses a tertiary aniline group, gave significantly greater chemiluminescence intensity upon reaction with $\left[\mathrm{Ru}(\mathrm{bpy})_{3}\right]^{2+}$ (and cerium(Iv)) than the other compounds, but this was not observed for $\left[\operatorname{Ir}(\text { df-ppy })_{2}(\mathrm{pt}-\mathrm{TEG})\right]^{+}$.

Previously examined iridium(III) complexes often exhibited higher chemiluminescence intensities than $\left[\mathrm{Ru}(\mathrm{bpy})_{3}\right]^{2+9,12}$ but also showed greater blank responses from the corresponding reaction with the solvent. However, this was not the case for $\left[\operatorname{Ir}(\mathrm{df}-\mathrm{ppy})_{2}(\mathrm{pt}-\mathrm{TEG})\right]^{+}$, which gave lower blank responses than $\left[\mathrm{Ru}(\mathrm{bpy})_{3}\right]^{2+}$. We suspected that this might be due to partial absorption of the blue emission of $[\operatorname{Ir}(\mathrm{df}$ ppy $)_{2}$ (pt-TEG) $]^{+}$by the cerium(Iv) oxidant, but the overlap of their emission and absorption spectra is minimal (Fig. 2a).|| Consequently, there was no red-shift in the chemiluminescence emission compared to the photoluminescence in the absence of cerium(Iv) (Fig. 2b): visually, the light emitted

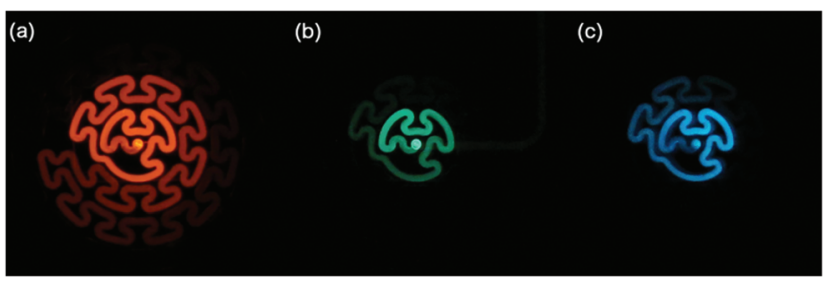

Fig. 4 Photographs of the chemiluminescence reactions of (a) $\left[\mathrm{Ru}(\mathrm{bpy})_{3}\right]^{2+}$ and 1-(4-trifluoromethylphenyl)piperdin-4-ol, (b) [Ir(ppy$\left.\left.\mathrm{SO}_{3}\right)_{2}(\mathrm{pt}-\mathrm{TEG})\right]^{-}$and 1-(4-trifluoromethylphenyl)piperazine, and (c) $\left[\operatorname{lr}(\mathrm{df}-\mathrm{ppy})_{2}(\mathrm{pt}-\mathrm{TEG})\right]^{+}$and furosemide, in aqueous solution. The metal complex reagents were continuously merged with an oxidant solution (cerium(Iv) sulfate in $0.05 \mathrm{M} \mathrm{H}_{2} \mathrm{SO}_{4}$ ) at a T-piece shortly prior to mixing with the other reactant solution within a transparent serpentine flowcell. ${ }^{22}$ A Canon 6D camera with $50 \mathrm{~mm}$ f1.8 lens were used (Canon, Japan). The exposure time and reactant concentrations were adjusted to produce similar emission intensities. 
<smiles>NS(=O)(=O)c1cc(C(=O)O)c(NCc2ccco2)cc1Cl</smiles><smiles>NS(=O)(=O)c1cc(C(=O)O)ccc1Cl</smiles>

(2) 4-chloro-3-sulfamoylbenzoic acid<smiles>NS(=O)(=O)c1cc(C(=O)O)c(NCc2ccccc2)cc1Cl</smiles><smiles>NS(=O)(=O)c1cc(C(=O)O)cc(N2CCCC2)c1Oc1ccccc1</smiles>

(4) piretanide

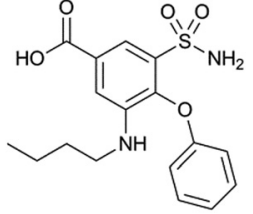

(5) bumetanide
Fig. 5 Loop diuretics and related compounds.

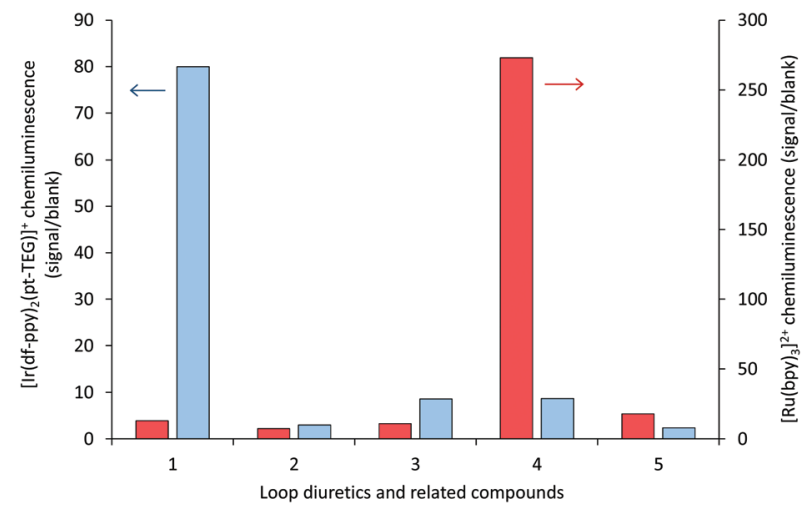

Fig. 6 Chemiluminescence responses (signal/blank ratios) of various loop diuretics and related compounds: (1) furosemide, (2) 4-chloro-3sulfamoyl-benzoic acid, (3) $\mathrm{N}$-benzyl-4-chloro-sulfamoylanthranillic acid, (4) piretanide, (5) bumetanide at $1 \mu \mathrm{M}$, with $\left[\mathrm{Ru}(\mathrm{bpy})_{3}\right]^{2+}$ (red columns) and [Ir(df-ppy) ${ }_{2}$ (pt-TEG) $]^{+}$(blue columns), using flow injection analysis methodology. Reagent concentration: $0.1 \mathrm{mM}$. Oxidant: $1 \mathrm{mM}$ cerium(Iv) sulfate in $0.05 \mathrm{M} \mathrm{H}_{2} \mathrm{SO}_{4}$. A comparison of signal/blank ratios for the two complexes with the same $y$-axis scale is shown in Fig. $\mathrm{S} 6$ in the ESI. $\dagger$

from the reaction of $\left[\operatorname{Ir}(\mathrm{df}-\mathrm{ppy})_{2}(\mathrm{pt}-\mathrm{TEG})\right]^{+}$with cerium(rv) sulfate and furosemide (Fig. 4) was the same blue colour as the corresponding photoluminescence (Fig. S3 $\dagger$ ).

Calibrations for furosemide (Fig. S7 $\dagger$ ) prepared using flow injection analysis methodology with $0.1 \mathrm{mM}\left[\operatorname{Ir}(\mathrm{df}-\mathrm{ppy})_{2}(\mathrm{pt}-\right.$ TEG) $]^{+}$(and $1 \mathrm{mM}$ cerium(Iv) sulfate in $0.05 \mathrm{mM} \mathrm{H}_{2} \mathrm{SO}_{4}$ ) showed a superior limit of detection $\left(1 \times 10^{-8} \mathrm{M} ; 3 \sigma\right)$ than that obtained with $\left[\mathrm{Ru}(\mathrm{bpy})_{3}\right]^{2+}\left(7 \times 10^{-8} \mathrm{M} ; 3 \sigma\right)$ under the same conditions. These detection limits are comparable to those reported in previous studies based on chemiluminescence reactions with $\left[\mathrm{Ru}(\mathrm{bpy})_{3}\right]^{2+}\left(8 \times 10^{-9} \mathrm{M}\right.$ to $\left.2 \times 10^{-7} \mathrm{M}\right){ }^{12,23,24}$
$\left[\mathrm{Ru}(\mathrm{BPS})_{3}\right]^{4-}\left(1 \times 10^{-8} \mathrm{M}\right.$ to $\left.\left.3 \times 10^{-8} \mathrm{M}\right)\right)^{18,24}$ and $[\operatorname{Ir}(\mathrm{df}-$ ppy $)_{2}($ BPS $\left.)\right]^{-}\left(1 \times 10^{-8} \mathrm{M}\right){ }^{12}$ where cerium(rv) was used as the oxidant.

\section{Conclusions}

These preliminary investigations of the $\left[\operatorname{Ir}(\mathrm{df}-\mathrm{ppy})_{2}(\mathrm{pt}-\mathrm{TEG})\right]^{+}$ complex as a chemiluminescence reagent reveal a viable approach to develop new detection systems based on chemically induced blue luminescence from metal complexes under analytically useful aqueous conditions. The use of polyethylene glycol groups is a more effective option to enhance solubility in water than previous attempts involving ligands with sulfonate groups. ${ }^{9,12}$ The ability to shift the emission bands into the blue region of the visible spectrum is advantageous for the development of miniaturised analytical devices with low-cost photodetectors. Moreover, the striking differences in the selectivity of these novel chemiluminescence reagents compared to traditional ruthenium(II) polypyridine complexes will expand the scope of chemiluminescence detection into new areas of application.

\section{Acknowledgements}

We thank the Australian Research Council (DP140100439, FT100100646) for funding this research.

\section{Notes and references}

$¥$ Similarly, water-soluble iridium-based catalysts have been prepared incorporating a tertiary phosphine ligand with multiple sulfonate substituents. ${ }^{25}$

$\S\left[\operatorname{Ir}(\mathrm{df}-\mathrm{ppy})_{2}(\mathrm{pt}-\mathrm{TEG})\right] \mathrm{Cl}$ and $\mathrm{Na}\left[\operatorname{Ir}\left(\mathrm{ppy}_{-} \mathrm{SO}_{3}\right)_{2}(\mathrm{pt}-\mathrm{TEG})\right]$ were prepared as previously described. ${ }^{16}\left[\mathrm{Ru}(\mathrm{bpy})_{3}\right] \mathrm{Cl}_{2} \cdot 6 \mathrm{H}_{2} \mathrm{O}$ was purchased from Strem (MA, USA).

ๆ Flow injection analysis was used to reproducibly combine the reactants. The manifold was assembled as described previously, ${ }^{11}$ which included a GloCel chemiluminescence detector (Global FIA, MA, USA) with dual-inlet serpentine flow-cell ${ }^{26}$ and an Electron Tubes model 9125B photomultiplier tube (ETP, NSW, Australia). The aqueous metal-complex reagent solutions were injected $(70 \mu \mathrm{L})$ into a carrier line containing the $1 \mathrm{mM}$ cerium(Iv) sulfate (in $0.05 \mathrm{M} \mathrm{H}_{2} \mathrm{SO}_{4}$ ), which merged with the analyte solution within the detection flow-cell. A flow rate of $3.5 \mathrm{~mL} \mathrm{~min}{ }^{-1}$ per line was used in all experiments.

|| Absorption spectra were obtained using Cary 300 Spectrophotometer. Photoluminescence spectra were obtained with a Cary Eclipse fluorescence spectrophotometer (5 $\mathrm{nm}$ excitation and emission band pass) and corrected for the wavelength dependence of the detector response and monochromator transmission. ${ }^{27}$ Chemiluminescence spectra were obtained by replacing the photomultiplier tube in the flow injection analysis manifold with an Ocean Optics QE65Pro spectrometer with CCD detector (10 s spectra integration time, each acquisition manually triggered in concert with reagent injection), which was interfaced with the chemiluminescence flow-cell via fibre optic cable $(1 \mathrm{~mm}$ core diameter, $1.0 \mathrm{~m}$ length) and collimating lens (30 mm diameter, 350-2000 $\mathrm{nm}$ ). This enabled measurement of the chemiluminescence spectrum after each injection, as the light-producing reaction mixture passed through the flow-cell. The presented chemiluminescence spectra are each an average of those obtained from three injections of the reagent solution into the flow injection analysis manifold. 
1 M. S. Lowry and S. Bernhard, Chem. - Eur. J., 2006, 12, 7970-7977; L. Flamigni, A. Barbieri, C. Sabatini, B. Ventura and F. Barigelletti, Top. Curr. Chem., 2007, 281, 143-203; Y. You and W. Nam, Chem. Soc. Rev., 2012, 41, 7061-7084.

2 A. Kapturkiewicz and G. Angulo, Dalton Trans., 2003, 39073913; P. Coppo, E. A. Plummer and C. L. De, Chem. Commun., 2004, 1774-1775; J. I. Kim, I.-S. Shin, H. Kim and J.-K. Lee, J. Am. Chem. Soc., 2005, 127, 1614-1615; K. N. Swanick, S. Ladouceur, E. Zysman-Colman and Z. Ding, Chem. Commun., 2012, 48, 3179-3181; E. H. Doeven, E. M. Zammit, G. J. Barbante, C. F. Hogan, N. W. Barnett and P. S. Francis, Angew. Chem., Int. Ed., 2012, 51, 4354-4357; E. H. Doeven, G. J. Barbante, E. Kerr, C. F. Hogan, J. A. Endler and P. S. Francis, Anal. Chem., 2014, 86, 2727-2732.

3 S. Zanarini, M. Felici, G. Valenti, M. Marcaccio, L. Prodi, S. Bonacchi, P. Contreras-Carballada, R. M. Williams, M. C. Feiters, R. J. M. Nolte, L. De Cola and F. Paolucci, Chem. - Eur. J., 2011, 17, 4640-4647.

4 J. Jia, H. Fei and M. Zhou, Electrophoresis, 2012, 33, 13971401; Q. Zhao, M. Yu, L. Shi, S. Liu, C. Li, M. Shi, Z. Zhou, C. Huang and F. Li, Organometallics, 2010, 29, 1085-1091.

5 S. Lin, W. Gao, Z. Tian, C. Yang, L. Lu, J.-L. Mergny, C.-H. Leung and D.-L. Ma, Chem. Sci., 2015, 6, 4284-4290.

6 X. Zhou, D. Zhu, Y. Liao, W. Liu, H. Liu, Z. Ma and D. Xing, Nat. Protoc., 2014, 9, 1146-1159; K. Muzyka, Biosens. Bioelectron., 2014, 54, 393-407.

7 R. V. Kiran, E. M. Zammit, C. F. Hogan, B. D. James, N. W. Barnett and P. S. Francis, Analyst, 2009, 134, 12971298.

8 M. Felici, P. Contreras-Carballada, Y. Vida, J. M. Smits, R. J. Nolte, L. De Cola, R. M. Williams and M. C. Feiters, Chem. - Eur. J., 2009, 15, 13124-13134; M.-J. Li, P. Jiao, W. He, C. Yi, C.-W. Li, X. Chen, G.-N. Chen and M. Yang, Eur. J. Inorg. Chem., 2011, 197-200.

9 J. Truong, K. B. Spilstead, G. J. Barbante, E. H. Doeven, D. J. D. Wilson, N. W. Barnett, L. C. Henderson, J. M. Altimari, S. C. Hockey, M. Zhou and P. S. Francis, Analyst, 2014, 139, 6028-6035.

10 B. A. Gorman, P. S. Francis and N. W. Barnett, Analyst, 2006, 131, 616-639.

11 J. M. Terry, E. M. Zammit, T. Slezak, N. W. Barnett, D. C. Olson, D. K. Wolcott, D. L. Edwards and P. S. Francis, Analyst, 2011, 136, 913-919.

12 E. M. Zammit, N. W. Barnett, L. C. Henderson, G. A. Dyson, M. Zhou and P. S. Francis, Analyst, 2011, 136, 3069-3072.

13 F. Wu, B. Tong and Q. Zhang, Anal. Sci., 2011, 27, 529-533; F. Wu, B. Tong, X. Wei and L. Chen, Luminescence, 2012, 27, 519-523; Y. P. Dong, L. Huang, B. H. Tong, M. J. Shi,
W. B. Zhang and Q. F. Zhang, Luminescence, 2012, 27, 262267; Y. P. Dong, M. J. Shi, B. H. Tong and Q. F. Zhang, Luminescence, 2012, 27, 414-418.

14 E. H. Doeven, E. M. Zammit, G. J. Barbante, P. S. Francis, N. W. Barnett and C. F. Hogan, Chem. Sci., 2013, 4, 977982.

15 G. J. Barbante, E. H. Doeven, E. Kerr, T. U. Connell, P. S. Donnelly, J. M. White, T. Lópes, S. Laird, C. F. Hogan, D. J. D. Wilson, P. J. Barnard and P. S. Francis, Chem. - Eur. J., 2014, 20, 3322-3332.

16 E. Kerr, E. H. Doeven, G. J. Barbante, T. U. Connell, P. S. Donnelly, D. J. D. Wilson, T. D. Ashton, F. M. Pfeffer and P. S. Francis, Chem. - Eur. J., 2015, 21, 14987-14995.

17 E. H. Doeven, G. J. Barbante, A. J. Harsant, P. S. Donnelly, T. U. Connell, C. F. Hogan and P. S. Francis, Sens. Actuators, $B, 2015,216,608-613$.

18 J. Xi, X. Ji, S. Zhang, X. Ai and Z. He, Anal. Chim. Acta, 2005, 541, 193-198.

19 L. Chen, X. Wang, H. Zhao, K. Wang and L. Jin, Luminescence, 2008, 23, 309-315; P. S. Francis and J. L. Adcock, Anal. Chim. Acta, 2005, 541, 3-12; B. Rezaei, T. Khayamian and A. Mokhtari, J. Pharm. Biomed. Anal., 2009, 49, 234239; R. J. Waite, G. J. Barbante, N. W. Barnett, E. M. Zammit and P. S. Francis, Talanta, 2013, 116, 10671072.

20 W. Miao, J.-P. Choi and A. J. Bard, J. Am. Chem. Soc., 2002, 124, 14478-14485.

21 C. M. Hindson, G. R. Hanson, P. S. Francis, J. L. Adcock and N. W. Barnett, Chem. - Eur. J., 2011, 17, 8018-8022; E. Kerr, E. H. Doeven, D. J. D. Wilson, C. F. Hogan and P. S. Francis, Analyst, 2016, 141, 62-69.

22 S. Mohr, J. M. Terry, J. L. Adcock, P. R. Fielden, N. J. Goddard, N. W. Barnett, D. K. Wolcott and P. S. Francis, Analyst, 2009, 134, 2233-2238.

23 F. Maya, J. M. Estela and V. Cerdà, Talanta, 2010, 80, 13331340.

24 G. P. McDermott, E. M. Zammit, E. K. Bowen, M. M. Cooke, J. L. Adcock, X. A. Conlan, F. M. Pfeffer, N. W. Barnett, G. A. Dyson and P. S. Francis, Anal. Chim. Acta, 2009, 634, 222-227.

25 H. Horváth, Á. Kathó, A. Udvardy, G. Papp, D. Szikszai and F. Joó, Organometallics, 2014, 33, 6330-6340; H. Horváth, G. Papp, R. Szabolcsi, Á. Kathó and F. Joó, ChemSusChem, 2015, 8, 3036-3038.

26 J. M. Terry, J. L. Adcock, D. C. Olson, D. K. Wolcott, C. Schwanger, L. A. Hill, N. W. Barnett and P. S. Francis, Anal. Chem., 2008, 80, 9817-9821.

27 P. S. Francis, J. L. Adcock and N. W. Barnett, Spectrochim. Acta, Part A, 2006, 65, 708-710. 